\title{
最確数法による生食用むき身貝中の推定腸炎 ビブリオ数の測定
}

(昭和 50 年 4 月 3 日受理)

$\begin{array}{rll}\text { 村上 - } \text { N1 }^{* 1} & \text { 神 保勝 彦*1 } & \text { 神 崎 政 子*1 } \\ \text { 小久保弥太郎 } & \text { 春田三佐夫*1 } & \text { 山田 満*2 }\end{array}$

\section{Enumeration of Presumptive Vibrio Parahaemolyticus in Edible Shucked Shellfish by the Use of Most Probable Number Technique}

\author{
Hajime Murakami, Katsuhiko Jinbo, Masako KanZaKI, Yataro KoKUBo, \\ Misao HARUTA and Mitsuru YAMADA \\ (*1Tokyo Metropolitan Research Laboratory of Public Health: 24-1, Hyakunin-cho \\ 3-chome, Shinjuku-ku, Tokyo; ${ }^{* 2}$ Sanitation Inspection Station of Central \\ Wholesale Market: 2-1, Tsukiji 5-chome, Chuo-ku, Tokyo)
}

Enumeration of presumptive $V$. parahaemolyticus in shucked shellish was made by a simple multiple tube technique with Arabinose-Colistin-Peptone-Water (ACPW). During the period June 1973 March 1975, Mactra chinensis and Scapharce broughlomii were obtained at Tokyo Central Wholesale Market. Throughout the surveys conducted on the incidence of the presumptive organism in the shellfish, it was found that when monitored mean MPN of the presumptive organism had exceeded the level of $10^{4} / \mathrm{g}$, a frequent occurrence of parahaemolyticus food poisoning patients was observed in Tokyo.

Although we were unable to prove the presence of Kanagawa positive organism among our isolates, we would like to propose following preventive measures for parahaemolyticus food poisoning; 1) Adoption of a tentative guide line "less than $10^{4} / \mathrm{g}$ " as an alowable limit of presumptive $V$. parahaemolyticus for marine products which might be consumed in a raw state; and 2) Labeling of "edible in raw" must be on the guaranteed, and prohibition of combined handling with other sort of sea products at retailers.

(Received April 3, 1975)

腸炎ビブリオ(以下腸ビと略す)の生態学的な研究結果 によれば, 日本の沿岸海水中には, 毎年晚春から初夏に かけて腸ビが出現し始め, 海水温の上昇とともにその数 を増すといわれている. しかし, 海の生態系を構成して いる海洋微生物の一つとして, 必ずある時期に出現する 腸ビと，そこに生育した魚介類の関係，すなわち，どの 種の魚介類が, どの時点で, ぞの程度の腸ビに污染され ていたかを定量的に，長期にわたって調査しな報告はこ れまでのところ見当たらない。ことに食品衛生の分野に

*1 東京都立衛生研究所, 生活科学部：新宿区百人町 3-24-1

*2 東京都市場衛生検査所: 中央区築地 5-2-1
おけるこの種の調査成績が欠除しているため，具体的な 腸ビ食中毒予防対策が立てられないのが現状であろう.

一方，我々日本人には，生魚介類を好む食習慣があ

り，これが我が国で腸ビ食中毒の発生が跡を断たない大 きな原因であろう。そこで我々としては, 生食用魚介類 の腸ビ活染安全許容レベル，すなわち可食限界を設定し て，そのレベル以上の污染食品を市場から排除する必要 があると考える、このような考え方に基ついて，今回 は，四季を通じて “すし種”として消費率の高いむき身 のバカ貝およびアカ貝中の腸ビの消長を, 長期にわたっ て定量的には握した。これと都内の腸ビ食中毒患者の発 生状沉と対比させ, 腸ビ污染の安全許容レベルを作製す 
る資料にしたいと考えた。

\section{材料および方法}

\section{1. 貝とその清水}

1973年 6 月から1975年 3 月に至る間，原則として 5 10 月は每週 1 回, その他の月は毎月 1 回定期的に, 東京 都中央卸売市場に入荷したバカ貝およびアカ貝のむき身 と，その漬水を10件ずつ採取し，検査に供した。

2. 培地

a) $6 \%$ 食塩加 $1 \%$ ペプトン水; 検体中に存在するこ との予想される寒冷損傷腸ビを, 選択培地中で発育でき るよう回復させるための予備培養液として，6\%食塩加 $1 \%$ ペプトン水 $(6 \%$ 食塩加 $\mathrm{PW})$ を用いた。 その組成 は, 食塩 $60 \mathrm{~g}$ と, ポリペプトン (大五栄養化学) $10 \mathrm{~g}$ を, 精製水 $1,000 \mathrm{ml}$ に溶解し, $\mathrm{pH} 7.2$ 亿調整したも のである.これを $10 \mathrm{ml}$ ずつ中試験管 $(18 \times 180 \mathrm{~mm})$ に分注し， $121^{\circ} て ゙ 15$ 分間隇菌した。なお，試料原液およ び漬水の原液の培養用に, 特に 2 倍濃度の予備培養液も 用意した。

b) アラビノース・コリスチン・ペプトン水; 前記予 備培養試験管中で, 他の海洋細菌などとともに, 回復増 殖した推定腸ビを選択的に増殖させ，最確数 (MPN) を 求めるためにアラビノース・コリスチン・ペプトン水 (ACPW) を用いた。その組成は，L-アラビノース $10 \mathrm{~g}$, 硫酸コリスチン (コリマイシン) 50 万単位，ポリペプト ソ (大五栄養化学) $10 \mathrm{~g}$, 食塩 $70 \mathrm{~g}$, およびフェノール レッド $0.02 \mathrm{~g}$ を精製水 $1,000 \mathrm{ml}$ に溶解し, $\mathrm{pH}$ を 7.8

\section{Solid sample}

$10 \mathrm{~g}$ of shellfish $\quad 90 \mathrm{ml}$ of the diluent

Homogenization at $20,000 \mathrm{rpm}$ for $1 \mathrm{~min}$

Serial 10 fold dilutions $\left(10^{-1} \sim 10^{-7}\right)$ of the suspension are made by the diluent

$1 \mathrm{ml}$ aliquots of the dilutions are delivered into triplicate tubes of $1 \%$ peptone water with $6 \% \mathrm{NaCl}$

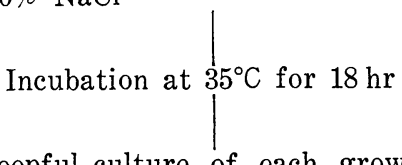

One loopful culture of each growth positive tube is subcultured into ACPW

\footnotetext{
Incubation at $35^{\circ} \mathrm{C}$ for $24 \mathrm{hr}$

Culculation of MPN
}

Scheme 1. Schematical presentation of the proposed enumeration technique for presumptive $V$. parahaemolyticus
に調整したものである.これを $3 \mathrm{ml}$ ずつ小試験管 $(13$ $\times 96 \mathrm{~mm})$ に分注し，隇菌せずに直ちに使用した。

\section{3. 希 勫 液}

試料原液の調製と希釈には，3\%食塩液 $800 \mathrm{ml}$ に, あらかじめ準備した $\mathrm{pH} 7.2$ リン酸緩衝液の原液 $1 \mathrm{ml}$ を加えた希釈液を用いた。試料原液の調製には $90 \mathrm{ml}$ つ, 希釈用としては $9 \mathrm{ml}$ ずつをそれぞれ $100 \mathrm{ml}$ 容希 釈ビンまたは中試験管 $(18 \times 180 \mathrm{~mm})$ に分注し，121で 15分間隇菌したものを用いた。なお，リン酸緩衝液の原 液は, リン酸 2 水素カリウム $\left(\mathrm{KH}_{2} \mathrm{PO}_{4}\right) 34 \mathrm{~g}$ を $500 \mathrm{ml}$ の精製水に溶解し，これに約 $1 N$ の水酸化ナトリウム 液 $175 \mathrm{ml}$ を加え, さらに蒸留水を加えて全量を 1,000 $\mathrm{ml}$ とし, $\mathrm{pH}$ を7.2に調整後, 使用時まで冷暗所に保存 した.

\section{4. 推定腸ビ数の測定}

貝 $10 \mathrm{~g}$ に希釈液 $90 \mathrm{ml}$ を加兄, $20,000 \mathrm{rpm}$ で 1 分 間細研し，これを試料原液とし $10^{-7}$ まで 10 倍段階希棌

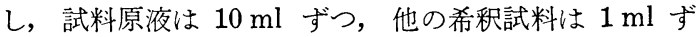
つ，それぞれ 3 本ずつの $6 \%$ 食塩加 $\mathrm{PW}$ 試験管に接種 した。次いで， $35^{\circ}$ で 18 時間培養後，菌の增殖が認め られたものを $\mathrm{ACPW}$ 試験管にそれぞれ 1 白金耳移植 し， $35^{\circ}$ で24時間培養後，アラビノース分解菌の 発育に より培地色の黄変したものを推定腸ビ陽性として，各希 釈列の陽性試験管数から，検体 $1 \mathrm{~g}$ 当たりの推定腸ビ MPN を求めた。なお，漬水の場合は，検体をそのまま 試料原液として，必要に応じてさらに希釉試料を調製

\section{Liquid sample}

Serial 10 fold dilutions $\left(10^{0} \sim 10^{-7}\right)$ of immersed water are made by the diluent 
Table 1. Incidence of Presumptive V. parahaemolyticus and of Total Bacteria on Shucked Shellfish, Compared with the Occurrence of Food Poisoning Patients in Tokyo

\begin{tabular}{|c|c|c|c|c|}
\hline \multirow{2}{*}{\multicolumn{2}{|c|}{ Date of sampling }} & \multicolumn{2}{|c|}{ Average viable cell count/g } & \multirow{2}{*}{$\begin{array}{l}\text { Weekly incidence } \\
\text { of food } \\
\text { poisoning patients }\end{array}$} \\
\hline & & $\begin{array}{c}\text { Presumptive } \\
V . \text { parahaemolyticus }\end{array}$ & Total bacteria & \\
\hline June & 25,1973 & $5.8 \times 10^{3}$ & $1.1 \times 10^{7}$ & 9 \\
\hline July & 2, 1973 & $1.1 \times 10^{4}$ & $4.4 \times 10^{6}$ & - \\
\hline July & 9,1973 & $6.2 \times 10^{4}$ & $3.0 \times 10^{6}$ & 31 \\
\hline July & 16,1973 & $1.5 \times 10^{4}$ & $7.3 \times 10^{8}$ & 179 \\
\hline July & 23,1973 & $5.4 \times 10^{4}$ & $9.3 \times 10^{8}$ & 146 \\
\hline July & 30,1973 & $1.0 \times 10^{5}$ & $8.8 \times 10^{6}$ & 132 \\
\hline Aug. & 6, 1973 & $2.2 \times 10^{5}$ & $9.8 \times 10^{8}$ & 58 \\
\hline Aug. & 13,1973 & $5.9 \times 10^{5}$ & $4.2 \times 10^{6}$ & 27 \\
\hline Aug. & 20,1973 & $1.2 \times 10^{6}$ & $2.6 \times 10^{8}$ & 12 \\
\hline Aug. & 27, 1973 & $7.8 \times 10^{5}$ & $9.4 \times 10^{5}$ & 100 \\
\hline Sept. & 3,1973 & $4.1 \times 10^{5}$ & $7.2 \times 10^{5}$ & 86 \\
\hline Sept. & 10, 1973 & $9.3 \times 10^{4}$ & $3.1 \times 10^{6}$ & 29 \\
\hline Sept. & 17,1973 & $5.5 \times 10^{4}$ & $1.9 \times 10^{6}$ & 47 \\
\hline Sept. & 25, 1973 & $6.6 \times 10^{3}$ & $5.5 \times 10^{8}$ & 118 \\
\hline Oct. & 1, 1973 & $2.1 \times 10^{4}$ & $2.0 \times 10^{8}$ & - \\
\hline Oct. & 8, 1973 & $3.6 \times 10^{3}$ & $7.4 \times 10^{6}$ & - \\
\hline Oct. & 15,1973 & $1.9 \times 10^{4}$ & $2.3 \times 10^{8}$ & - \\
\hline Oct. & 22,1973 & $7.4 \times 10^{3}$ & $5.5 \times 10^{8}$ & - \\
\hline Oct. & 29,1973 & $1.5 \times 10^{4}$ & $4.1 \times 10^{8}$ & - \\
\hline Nov. & 5, 1973 & $2.8 \times 10^{2}$ & $8.0 \times 10^{5}$ & - \\
\hline Nov. & 12,1973 & $1.4 \times 10^{2}$ & $3.3 \times 10^{5}$ & - \\
\hline Nov. & 19, 1973 & $2.1 \times 10^{2}$ & $1.6 \times 10^{5}$ & - \\
\hline Nov. & 26,1973 & $8.0 \times 10^{0}$ & $1.0 \times 10^{5}$ & - \\
\hline Dec. & 17, 1973 & $<0.3 \times 10^{0}$ & $6.7 \times 10^{5}$ & - \\
\hline Jan. & 21,1974 & $<0.3 \times 10^{0}$ & $9.7 \times 10^{3}$ & - \\
\hline Feb. & 18, 1974 & $<0.3 \times 10^{0}$ & $2.1 \times 10^{5}$ & - \\
\hline March & 18,1974 & $<0.3 \times 10^{0}$ & $4.5 \times 10^{5}$ & - \\
\hline April & 22,1974 & $7.4 \times 10^{0}$ & $8.0 \times 10^{5}$ & - \\
\hline May & 7, 1974 & $2.7 \times 10^{0}$ & $2.0 \times 10^{5}$ & - \\
\hline May & 13,1974 & $0.9 \times 10^{0}$ & $6.4 \times 10^{5}$ & - \\
\hline May & 20,1974 & $1.4 \times 10^{1}$ & $1.3 \times 10^{6}$ & - \\
\hline May & 27,1974 & $1.6 \times 10^{2}$ & $6.0 \times 10^{5}$ & - \\
\hline June & 3, 1974 & $1.7 \times 10^{2}$ & $1.4 \times 10^{6}$ & - \\
\hline June & 10,1974 & $5.2 \times 10^{2}$ & $6.0 \times 10^{6}$ & 1 \\
\hline June & 17,1974 & $1.2 \times 10^{3}$ & $5.3 \times 10^{6}$ & - \\
\hline June & 24,1974 & $4.9 \times 10^{3}$ & $5.0 \times 10^{6}$ & - \\
\hline July & 1,1974 . & $2.5 \times 10^{3}$ & $3.0 \times 10^{8}$ & - \\
\hline July & 8, 1974 & $1.3 \times 10^{3}$ & $1.9 \times 10^{8}$ & - \\
\hline July & 15,1974 & $1.6 \times 10^{2}$ & $2.6 \times 10^{8}$ & 4 \\
\hline July & 22,1974 & $1.9 \times 10^{3}$ & $2.4 \times 10^{6}$ & 9 \\
\hline July & 29,1974 & $2.0 \times 10^{3}$ & $3.2 \times 10^{6}$ & 10 \\
\hline Aug. & 5, 1974 & $5.3 \times 10^{3}$ & $1.2 \times 10^{7}$ & 33 \\
\hline
\end{tabular}


(continued)

\begin{tabular}{|c|c|c|c|c|}
\hline \multirow{2}{*}{\multicolumn{2}{|c|}{ Date of sampling }} & \multicolumn{2}{|c|}{ Average viable cell count/g } & \multirow{2}{*}{$\begin{array}{l}\text { Weekly incidence } \\
\text { of food } \\
\text { poisoning patients }\end{array}$} \\
\hline & & $\begin{array}{c}\text { Presumptive } \\
V . \text { parahaemolyticus }\end{array}$ & Total bacteria & \\
\hline Aug. & 12,1974 & $4.3 \times 10^{4}$ & $1.8 \times 10^{7}$ & 15 \\
\hline Aug. & 19,1974 & $5.1 \times 10^{2}$ & $2.3 \times 10^{8}$ & 18 \\
\hline Aug. & 26,1974 & $1.4 \times 10^{4}$ & $4.7 \times 10^{6}$ & 15 \\
\hline Sept. & 2,1974 & $1.3 \times 10^{4}$ & $1.0 \times 10^{6}$ & 17 \\
\hline Sept. & 9,1974 & $1.2 \times 10^{4}$ & $3.0 \times 10^{6}$ & 4 \\
\hline Sept. & 17,1974 & $1.9 \times 10^{3}$ & $5.6 \times 10^{5}$ & 4 \\
\hline Sept. & 24,1974 & $1.3 \times 10^{3}$ & $3.1 \times 10^{5}$ & - \\
\hline Sept. & 30,1974 & $7.6 \times 10^{2}$ & $5.3 \times 10^{6}$ & 18 \\
\hline Oct. & 7,1974 & $6.3 \times 10^{1}$ & $6.2 \times 10^{5}$ & 5 \\
\hline Oct. & 14,1974 & $3.0 \times 10^{1}$ & $2.3 \times 10^{5}$ & - \\
\hline Oct. & 21,1974 & $1.1 \times 10^{1}$ & $1.6 \times 10^{8}$ & - \\
\hline Oct. & 28,1974 & $5.0 \times 10^{0}$ & $4.6 \times 10^{5}$ & - \\
\hline Nov. & 5,1974 & $0.3 \times 10^{0}$ & $7.8 \times 10^{4}$ & - \\
\hline Dec. & 9,1974 & $<0.3 \times 10^{0}$ & $1.1 \times 10^{5}$ & - \\
\hline Jan. & 20,1975 & $<0.3 \times 10^{0}$ & $1.6 \times 10^{5}$ & - \\
\hline Feb. & 24,1975 & $<0.3 \times 10^{0}$ & $5.5 \times 10^{4}$ & - \\
\hline March & 17,1975 & $<0.3 \times 10^{0}$ & $4.8 \times 10^{5}$ & - \\
\hline
\end{tabular}

し，貝の場合と同様に検査した (Scheme 1).

\section{5. 一般細菌数の測定}

試料原液㧍よび希釈試料の $0.1 \mathrm{ml}$ をそれぞれ，3\% 食塩加普通寒天 (ニッスイ) 平板上にコンラージ棒で叙 抹し， $25^{\circ}$ で72時間培養し，出現したコロニ一数を算定 して一般細菌数とした。

\section{成 績}

1.むき身貝中の推定腸ビ数, 一般細菌数の消長と都 内腸ビ食中毒患者発生の関係

1973年 6 月から1975年 3 月までの 22 力月間に, 東京都 中央卸売市場に入荷した，むき身貝の推定腸ビ菌数と一 般細菌数を経時的には握し, 同時期に発生した確認腸ビ 食中毒患者数と対比させてみた (Table 1).

1973年 6 月 25 日の時点で, $10^{3} / \mathrm{g}$ レベルにあった平均 推定腸ビ数は, 日数の経過に伴い急速に堌加し, 8 月 20 日には $10^{8} / \mathrm{g}$ レベルとその最高値に達した。 以後徐々に その菌数の減少をみせ, 11 月 5 日には $10^{2} / \mathrm{g}$ レベルまで 低下し，12月17日には全く検出できなくなった。 その 後, 貝の中から推定腸ビが検出できなかった期間は, 1974年 3 月18日までにわたっていた.

推定腸ビが再び貝の中に出現し始めたのは，1974年 4 月22日からで，以後その数以徐々に増加し，6月中旬に は前年同様 $10^{3} / \mathrm{g} レ$ レルに到達した。しかし，以後 8 月 上旬まで $10^{3} / \mathrm{g}$ レベルの菌数を維持し，わずかに 8 月中 旬から 9 月上旬までの間, $10^{4} / \mathrm{g}$ を越える時期があった
が，再び急激に減少し，12月上旬には全く検出できなく なった。

以上，両年の検查結果から，むき身貝中の推定腸ビ数 は，季節の変化とともに顕著な変動を示し，しかも平均 推定腸ビ数が $10^{4} / \mathrm{g}$ レベルを越えた時期に, 腸ビ食中毒 患者の発生頻度が高くなることが分かった。一方, 検体 中の一般細菌数は, 年間を通じて $10^{8} / \mathrm{g}$ 前後を示し, 海 水温が最も低下寸ると考えられる $1 \sim 2$ 月の時点でも, 大きな変動は認められなかった。

\section{2. 貝と清水中の推定腸ビ数の比較}

貝とその漬水それぞれ 177 件の推定腸ビ数を比較した ところ (Table 2), そのうち150件 $(84.7 \%)$ について, 1 オーダー以内の差で，ほぼ似通った測定値が得られ た。しかし，この表から明らかなように，一般に貝の推 定腸ビ数が漬水のそれよりもわずかに高くでる傾向が認 められた。 その原因を明らかにするため，“舌切り”お よび “さき赤”という商品名を付されている加工バカ貝 およびアカ貝の漬水 140 件の塩分濃度を調べてみたとこ ろ，そのらち 133 件 $(95 \%)$ が塩分濃度 $1 \%$ 以下で, 明 らかにむき身貝の加工業者が墑品を水增しする目的で， 貝の漬水に水道水を用いていることが判明した。

\section{3. 分離腸ビ株の性状}

検体の MPN 測定に用いた ACPW で，陽性を示し た最高希釈列の試験管から，その 1 白金耳を TCBS (栄 研化学(株)製) 平板に接種し, 菌を分離した後, その生 
Table 2. Simultaneous Detection of Presumptive V. parahaemolyticus from Shucked Shellfish and Its Immersed Water

\begin{tabular}{|c|c|c|c|c|c|c|c|c|}
\hline & \multicolumn{6}{|c|}{ MPN on shellfish (per gram) } & \multirow{2}{*}{ Total } \\
\hline & & $<10^{2}$ & $10^{2} \sim 10^{3}$ & $10^{3} \sim 10^{4}$ & $10^{4} \sim 10^{5}$ & $10^{5} \sim 10^{8}$ & $>10^{6}$ & \\
\hline \multirow{6}{*}{ 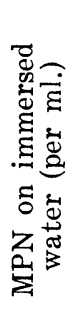 } & $<10^{2}$ & 13 & 2 & 4 & 3 & \multirow[t]{2}{*}{1} & \multirow[b]{3}{*}{1} & \multirow{2}{*}{$\begin{array}{l}23 \\
36\end{array}$} \\
\hline & $10^{2} \sim 10^{3}$ & & 7 & 21 & 8 & & & \\
\hline & $10^{3} \sim 10^{4}$ & \multirow[t]{4}{*}{$\overline{2}$} & 4 & 23 & 15 & 4 & & 49 \\
\hline & $10^{4} \sim 10^{5}$ & & 1 & 3 & 11 & 15 & 2 & 32 \\
\hline & $10^{5} \sim 16^{6}$ & & & 1 & 3 & \multirow[t]{2}{*}{27} & 3 & 34 \\
\hline & $>10^{8}$ & & & & & & 3 & 3 \\
\hline \multicolumn{2}{|c|}{ Total } & 15 & 14 & 52 & 40 & 47 & 9 & 177 \\
\hline
\end{tabular}

Note: Figures in the Table indicate the number of specimens.

Table 3. Results of Serological Typing Made on the Isolates

\begin{tabular}{|c|c|c|c|c|c|c|c|c|c|c|c|c|c|}
\hline \multirow{2}{*}{ O Group } & \multicolumn{12}{|c|}{ K Types } & \multirow{2}{*}{ Total } \\
\hline & 18 & 29 & 30 & 32 & 33 & 34 & 37 & 39 & 42 & 51 & 56 & KUT & \\
\hline 1 & \multirow{12}{*}{1} & \multirow{12}{*}{$1^{\text {a) }}$} & \multirow{12}{*}{1} & \multirow[t]{12}{*}{2} & \multirow[t]{12}{*}{7} & \multirow{12}{*}{1} & \multirow{12}{*}{4} & \multirow{12}{*}{1} & \multirow{12}{*}{16} & \multirow{12}{*}{1} & 4 & 2 & 15 \\
\hline 2 & & & & & & & & & & & \multirow{11}{*}{$2^{\mathrm{a})}$} & 2 & 2 \\
\hline 3 & & & & & & & & & & & & 13 & 19 \\
\hline 4 & & & & & & & & & & & & 5 & 23 \\
\hline 5 & & & & & & & & & & & & \multirow{5}{*}{5} & 1 \\
\hline 6 & & & & & & & & & & & & & 1 \\
\hline 7 & & & & & & & & & & & & & 0 \\
\hline 8 & & & & & & & & & & & & & 6 \\
\hline 9 & & & & & & & & & & & & & 0 \\
\hline 10 & & & & & & & & & & & & 5 & 5 \\
\hline 11 & & & & & & & & & & & & & 1 \\
\hline 12 & & & & & & & & & & & & & 0 \\
\hline Total & 1 & 1 & 1 & 2 & 7 & 1 & 4 & 1 & 16 & 1 & 6 & 32 & 73 \\
\hline
\end{tabular}

a) Indicates the number of strains showed new $\mathrm{O}-\mathrm{K}$ antigenic combination, and $\mathrm{KUT}$ indicates $\mathrm{K}$ untypable.

物学的性状1)を調べたところ, 分離株のすべてが神奈川 現象 ${ }^{2)}$ 陰性であった点を除いて，患者分離標準株の示す 性状を満足し，腸ビと同定された。 なお，分離株のらち 代表的とおもわれる73株について，その抗原型を調べた ところ (Table 3)，41株 $(56.2 \%)$ が既知のK抗原型に型 別された。 しかし，そのらちの 3 株はこれまで知られて いなかった $\mathrm{O}$ 一 $\mathrm{K}$ 抗原型であった。. 残りの 32 株 (43.8\%) についてはK抗原による型別は不能であった。

考察

鮮魚介類など食品からの腸ビ分離に際して，常に次の
点が考慮されなければならない，1）菌分離の方法とし て，通常食中毒患者䔬便から腸ビを分離する方法に準じ て TCBS 平板上に直接試料原液を塗抹接種する方法で は, 白糖非分解の海水由来類縁ビブリオが，同時に腸ビ に類似の集落を形成するため, 腸ビ集落との判別が困難 であり，しかも検体中 $10^{2} / \mathrm{g}$ 以下の腸ビ数を測定できな い，2）低温保存検体にあっては，污染腸ビが 寒冷傷害 を受けており，選択培地上での増殖が抑制されるため， 実際よりかなり低い数值しか得られない.

最近これらの難点を克服するために，MPN 法によ 


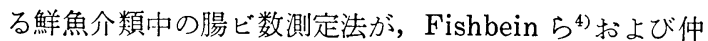
西らすにによって報告されているが，菌の分離同定を含め て最終的な MPN 值を得るまでの手技が複雑であるな ぞ,な扣多くの難点がある。 今回の調査で我々が採用し た方法は, 検体中に存在の予想される損傷腸ビの回復を 計るとともに，ある程度類縁ビブリオの增殖を抑制する ため, まず $6 \%$ 食塩加 $\mathrm{PW}$ で予借培養をした後, これ を $\mathrm{ACPW}$ 培地に移植して, 培地中に含まれる L-アラビ ノースの分解の有無を鍵として推定腸ビ数を得ようとす る簡易法である.

1973年に, この方法で调べた貝中の平均推定腸 ビ数 が， $10^{4}$ から $10^{8} / \mathrm{g}$ と急上昇すると同時に, 都内に腸ビ 食中毒患者が多発したことから，1974年は，市場に出回 る貝の中の推定腸ビ数を $10^{3} / \mathrm{g}$ 以下に抑えるとい5目標 を設定してみた。まず，市場に大量にむき身貝を出荷し ている千葉県浦安の加工業者に対する指導を 7 月から 9 月まで重点的に行い, 徒来, 48 時間を要した産地 $\rightarrow$ 輸

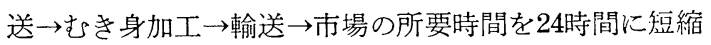
させた，同時に，むき身加工後の低温流通の徹底を計 り, 市場内での貝と他の魚介類との混売を禁止し, 両者 間の交叉污染の防止を計った。その結果，7月中の貝の 推定腸ビ数は, 一応期待通り $10^{3} / \mathrm{g}$ レベルを維持し続 け，わずかに 8 月中旬以後 9 月初旬まで $10^{4} / \mathrm{g}$ レベルを 示したのみで, 以後急速な下降を示した。一方, 都内の 腸ビ食中毒患者数も，1974年には大幅な減少を示し，し かも貝類に起因するものは皆無といら好成績を得た。 そ こで「生食用海産魚介類中の推定腸ビ数は $10^{3} / \mathrm{g}$ レベル 以下でなければならない」といら暫定許容限界を設け, 生産から消費にいたる間，一貫した低温流通を計るとと もに, 小売店での販売に際しては, 生食用の標示を付 し，その他一般の鮮魚介類との混売を禁止すべきである と考光る.なお, Table 2 から明らかなように, 漬水の 推定腸ビ数は, 貝のそれとお打む极一致するので, 末端 小売店舗での調査の際には, 経济的損害を与えない意味 で, 漬水のみを検查対象として污染度調查を行うことも 意義のあることと思われる.

腸ビのヒトに対する病原性については, 宮本ら²)の述 べた神奈川現象の有無と, 滝川 ${ }^{8)}$ および坆崎ら ${ }^{7)}$ の行っ た実験の結果から, 海産物由来の腸ビのほとんどは, 非 病原性株であると考劣られている。ところが，我妻量は， 海洋由来株 748 株中 1 株が，神奈川現象陽性であったと し，善養寺ら ${ }^{3)}$ も，食中毒の原因食として疑われた魚介 類から得た，167株の腸ビ株中 6 株 $(3.6 \%)$ が神奈川現 象陽性であったと述べている。現在むで, 我々は, 本調 査で神奈川現象陽性株を得ていないし，また我々の分離

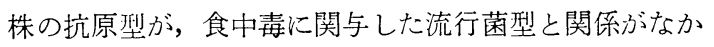
ったことから, 我々が測定している推定腸ビ数が, 神奈
川現象陽性腸ビの存在と, どのような関係にあるかにつ いては論及できない。しかし, 市場に出回る生食用魚介 類が，七トに病原性を示す腸ビに污染されている恐れの 度合を, この推定腸ビを指標菌として推测することは可 能と思われる. また, 污染状況の追跡の対象海産物とし て, バカ貝などは, 四季を通じて市場に出回る食品であ るので, これらが生産された日本の沿岸海域の, 腸ビ污 染状況を孔併せて推測できるなど，この種の調査に最も 適した検查対象の一つと考える。

\section{要 約}

1973年 6 月から1975年 3 月まで，生食用むき身バカ貝 およびアカ貝を対象とした腸ビ污染の追跡を行ったとこ ろ, 推定腸ビ数が $10^{4} / \mathrm{g}$ レベルを越えた時期に，腸ビ食 中毒患者が多発する傾向が認められた。漬水についても これと同様な傾向がみられた。一方, 検体中の一般海洋 細菌数は, 年間を通じて大きな变動は認められず, $10^{8} / \mathrm{g}$ 前後を示した。

陽性反応を示した最高希釈列の ACPW から，TCBS 平板で分離した分離株はすべて神奈川現象陰性であった が，生物学的性状から腸ビと同定された。また，その抗 原型を調べたところ，分離株の $56.2 \%$ が既知の血清型に 型別された。しかし，これら分離株の抗原型は，食中毒 に関与した流行菌型と関係がなかった。

なお，今回の調査で採用した検査法ならびに成績の一 部は, 第 27 回日本食品衛生学会 (昭和 49 年 5 月, 東京) において発表した。

\section{文献}

1) LeClair, R., Zen-Yoji, H., Sakai, S.: J. Conference of Public Health Laboratory Directors, 28, 82 (1970).

2) Miyamoto, Y., Kato, T., Ohara, Y., Akiyama, S., Takizawa, K., Yamai, S.: J. Bacteriol., 100, 1147 (1969).

3) Zen-Yoji, H., Sakai, S., Kudoh, Y., Itoh, T., Terayama, T.: Health Laboratory Service, 7, 100 (1970).

4) Fishbein, M., Wentz, B.: J. Milk Food Technol., 36, 118 (1973).

5) Nakanishi, H., Murase, M.: Proc. International Symposium on $V$. parahaemolyticus, p. 117 (1974) Saikon Publishing Co.

6) Takikawa, I.: Yokohama Medical Bulletin, 9, 313 (1958).

7) 坂崎利一, 田村和満, 加藤貞治, 小原 寧: メ ディヤサークル，13，159 (1968).

8) 我妻正三郎: 同上, 13, 159 (1968). 